\title{
Simultaneous effusive and explosive cinder cone eruptions at Veniaminof Volcano, Alaska
}

\author{
Christopher F. Waythomas \\ US Geological Survey, Alaska Volcano Observatory, 4230 University Dr. Suite 100, Anchorage, Alaska 99508, USA.
}

\begin{abstract}
Historical eruptions of Veniaminof Volcano, Alaska have all occurred at a 300-m-high cinder cone within the icefilled caldera that characterizes the volcano. At least six of nineteen historical eruptions involved simultaneous explosive and effusive activity from separate vents. Eruptions in 1944, 1983-1984, 1993-1994, 2013, 2018 and 2021 included periods of explosive ash-producing Strombolian activity from summit vents and simultaneous nonexplosive effusion of lava from flank vents on either the southern or northeast sides of the cone. A T-junction conduit network is proposed to explain the simultaneous eruptive styles and as a mechanism for gas-magma segregation that must occur to produce the observed activity. Historical eruptions with simultaneous summit and flank activity produced slightly higher rising ash clouds compared to historical eruptions where simultaneous activity did not occur. This could be a consequence of the partitioning of more gas-charged magma into the vertical conduit of a T-junction conduit system.
\end{abstract}

Keywords: Veniaminof Volcano; Cinder cone eruptions; Conduit network;

\section{INTRODUCTION}

Study of historical eruptive activity at hazardous volcanoes guides our understanding of the styles and outcomes of future eruptions. It also informs decisions about how to monitor unrest and measure the signals being generated by the volcano of interest. Since the year 2000, $61 \%$ of known eruptions of VEI (Volcano Explosivity Index) 3 or greater have involved both effusive and explosive activity [Cassidy et al. 2018]. Simultaneous tephra emission and lava effusion is also a characteristic of many cinder cone eruptions [Krauskopf 1948; Luhr et al. 1993; Valentine et al. 2007; Pioli et al. 2008; Kiyosugi et al. 2013; Jordan et al. 2016; Smith and Németh 2017]. The dichotomy of eruptive styles poses a variety of non-trivial problems for real-time hazard assessment and thus the causes of this behavior and methods for detecting it merit further study and analysis.

Historical cinder cone eruptions at Veniaminof Volcano in Alaska (Figure 1) provide examples of lava effusion and Strombolian explosive activity occurring at the same time. Although the volcano is remote with few people and little infrastructure nearby, occasional violent Strombolian explosions (Table 1) have generated ash clouds that exceeded $6 \mathrm{~km}$ above sea level and thus are important hazards to aircraft. Simultaneous explosive and effusive activity also has important implications for the partitioning of multiphase flows of magma and gas that influence the degree of explosive behavior at vents above vertical conduits while lateral conduits erupt effusive lavas [Pioli et al. 2009].

${ }^{*}$ Corresponding author: cwaythomas@usgs.gov

\section{Veniaminof Volcano}

Veniaminof Volcano is a basalt-to-dacite stratovolcano about $350 \mathrm{~km}^{3}$ in volume, located on the Alaska Peninsula $(56.2 \mathrm{~N},-159.4 \mathrm{~W})$ (Figure 1). The volcano is characterized by an 8 by $10 \mathrm{~km}$ diameter ice-filled summit caldera (highest point on the caldera rim is $2507 \mathrm{~m}$ above sea level) that formed and was subsequently enlarged during three significant eruptions in late Pleistocene-Holocene time [Miller et al. 2002]. Veniaminof is covered by about $273 \mathrm{~km}^{2}$ of glacial ice and an even greater amount of ice covered the volcano during times of Pleistocene glacial maxima [Detterman et al. 1981]. The flanks of the volcano are deeply incised by glacier erosion and numerous glaciated valleys with nearly vertical valley walls are characteristic except on parts of the south flank where a broad lobe of ice drapes over a morphologically subdued caldera rim (Figure 1).

Veniaminof is one of the largest and most active volcanoes in the Aleutian arc and has erupted at least 19 times since 1830-1840 [Table 1; Miller et al. 1998]*. Historical eruptions have been mostly small to moderate Strombolian events (VEI 1-3) characterized by intermittent periods of lava fountaining, explosions, low-level emissions of ash and gas and occasional lava flows (Table 1). Ash plumes associated with historical eruptions have been relatively small and usually do not reach more than about 4-6 km above sea level. Occasional stronger bursts of activity have generated higher rising plumes, such as during the 1939 and 1956 eruptions when ash plumes rose to an estimated $>6 \mathrm{~km}$ above sea level [Miller et al. 1998], and during

${ }^{*}$ wWw . avo.alaska.edu 
Table 1: Historical eruptions of Veniaminof volcano. $U=$ unknown, $L=$ likely, $Y=$ yes, $N=$ no. "Location" refers to the location of activity on cone A. Volcano Explosivity Index (VEI) values are estimates and in many cases not confirmed with known eruptive volumes. Data from www . avo . alaska. edu.

\begin{tabular}{|c|c|c|c|c|c|c|}
\hline \multirow{2}{*}{ Date } & \multirow{2}{*}{ Duration } & \multicolumn{2}{|c|}{ Location } & \multirow{2}{*}{$\begin{array}{l}\text { Maximum } \\
\text { ash cloud } \\
\text { height }(\mathrm{km})\end{array}$} & \multirow{2}{*}{ VEI } & \multirow{2}{*}{ Comments } \\
\hline & & Summit & Flank & & & \\
\hline $1830-1840$ & $\mathrm{U}$ & $\mathrm{L}$ & $\mathrm{U}$ & $\mathrm{U}$ & $2 ?$ & $\begin{array}{l}\text { "Flames" and ash emissions observed } \\
\text { sometime during nine-ten year pe- } \\
\text { riod. }\end{array}$ \\
\hline 1852 & $\mathrm{U}$ & $\mathrm{L}$ & $\mathrm{U}$ & $\mathrm{U}$ & $\mathrm{U}$ & Ash emissions. \\
\hline 1892 & 3 days & $\mathrm{L}$ & $\mathrm{U}$ & 3.2 & $3 ?$ & $\begin{array}{l}\text { Explosions, roaring sounds, lava } \\
\text { fountaining, ash emission. }\end{array}$ \\
\hline Nov 1939 & $\mathrm{U}$ & $\mathrm{L}$ & $\mathrm{U}$ & $\mathrm{U}$ & $2 ?$ & Ash emission. \\
\hline May-June 1939 & 28 days & $\mathrm{L}$ & $\mathrm{U}$ & 6.1 & $3 ?$ & $\begin{array}{l}\text { Explosions, ash emission, lava foun- } \\
\text { taining. }\end{array}$ \\
\hline 1944 & Weeks & Y & $\mathrm{Y}$ & $\mathrm{U}$ & $2 ?$ & $\begin{array}{l}\text { Ash emissions, flank vent lava flows, } \\
\text { see Figure 2A. }\end{array}$ \\
\hline 1956 & $\sim 3$ months & $\mathrm{L}$ & $\mathrm{U}$ & 6.1 & $3 ?$ & Ash emissions. \\
\hline 1983-1984 & $\sim 10$ months & Y & $\mathrm{Y}$ & 7.8 & 3 & $\begin{array}{l}\text { Ash emissions, flank vent lava flows, } \\
\text { lava fountaining. }\end{array}$ \\
\hline 1984 & $\sim 10$ days & $\mathrm{L}$ & $\mathrm{N}$ & 5.4 & $2 ?$ & Explosions, ash emissions in bursts. \\
\hline 1993-1994 & $\sim 13$ months & Y & $\mathrm{Y}$ & 5.5 & 2 & $\overline{\text { Ash emissions, flank vent lava flows. }}$ \\
\hline 1995 & $\sim 7$ months & Y & $\mathrm{L}$ & $\mathrm{U}$ & $1-2 ?$ & Explosions, possible flank lava flows. \\
\hline $2002-2003$ & $\sim 5$ months & $\mathrm{Y}$ & $\mathrm{N}$ & $<1.0$ & 1 & $\begin{array}{l}\text { Minor steam and ash bursts, explo- } \\
\text { sions, ash emissions. }\end{array}$ \\
\hline 2004 & $\sim 7$ months & Y & $\mathrm{N}$ & 3.5 & 2 & Steam and ash bursts. \\
\hline 2005 & $\sim 1.5$ months & Y & $\mathrm{N}$ & 4.0 & 2 & $\begin{array}{l}\text { Minor lava fountaining, steam and } \\
\text { ash bursts. }\end{array}$ \\
\hline 2005 & $\sim 3$ months & Y & $\mathrm{N}$ & 3.0 & 1 & $\begin{array}{l}\text { Minor ash emissions, ash and steam } \\
\text { bursts. }\end{array}$ \\
\hline 2006 & $\sim 8$ months & Y & $\mathrm{N}$ & 2.3 & 1 & Intermittent steam and ash bursts. \\
\hline 2013 & $\sim 4$ months & Y & $\mathrm{Y}$ & 6.1 & $2-3$ & $\begin{array}{l}\text { Ash emissions, flank lava flows, lava } \\
\text { fountaining. }\end{array}$ \\
\hline 2018 & $\sim 4$ months & Y & $\mathrm{Y}$ & 4.9 & 2 & $\begin{array}{l}\text { Ash emissions, flank lava flows, lava } \\
\text { fountaining. }\end{array}$ \\
\hline 2021 & $\sim 1.5$ months & Y & Y & 3.0 & 1 & $\begin{array}{l}\text { Ash emissions, subglacial flank lava } \\
\text { flows. }\end{array}$ \\
\hline
\end{tabular}

the 1983-1984 eruption when the largest ash plume reached a height of $8 \mathrm{~km}$ above sea level [Yount et al. 1985]. During the 2018 eruption, an ash cloud reached a height of about $4.5 \mathrm{~km}$ above sea level on November 21, 2018.

The caldera icefield has a level flat surface that is interrupted by two constructional cones that extend above the ice surface (Figure 1). The northernmost cone (cone B) is exposed only during times of low snow cover, but is clearly a positive topographic feature within the caldera icefield. The eruptive history of cone $B$ is unknown, and one sample of lava collected in 1973 is basaltic in composition $\left(53.1 \% \mathrm{SiO}_{2}\right.$ [Yount et al. 1985]). The second intracaldera cone, cone A (Figure 2), is located near the head of Cone glacier and it has been the site of all known historical eruptions at Veniaminof Volcano. Cone A has about $300 \mathrm{~m}$ of relief above the surrounding icefield, covers an area of about $3 \mathrm{~km}^{2}$ and has a volume of at least $0.08 \mathrm{~km}^{3}$; its absolute size is unknown because some amount of the cone is covered 
by ice and snow. Cone A is typically snow-free yearround and is visible from locations outside the caldera both north and south of the volcano. Cone A has several active fumaroles and small explosion craters on its surface that commonly change location with the passing of each new episode of unrest. The cone itself is composed of rubbly ' $a$ 'à lava flows interbedded with near vent spatter, bombs, lapilli, and ash. Two lava samples collected in 1973-1974 contained 53.8 and $55.4 \% \mathrm{SiO}_{2}$. Several samples of the lava flows erupted in 2018 contained 53.5-54.5\% $\mathrm{SiO}_{2}$ [Loewen et al. 2021] indicating that eruptive products produced by cone A are basaltic to basaltic andesite in composition.

Pyroclastic-flow, lahar, and tephra deposits of Holocene age mantle the distal flanks of the volcano and record multiple caldera-forming eruptions and several smaller explosive events [Miller and Smith 1987; Miller et al. 2002; Waythomas et al. 2015]. The pre-Holocene eruptive history of the volcano is constrained by ${ }^{40} \mathrm{Ar} /{ }^{39} \mathrm{Ar}$ and $\mathrm{K}-\mathrm{Ar}$ dating of basalt, andesite, and dacite lavas and indicates a $340 \mathrm{ka}$ long record of eruptive activity punctuated by the calderaforming eruptions of the late Quaternary [Calvert et al. 2005; Bacon et al. 2007].

\section{EVIDENCE FOR SIMULTANEOUS EFFUSIVE AND EXPLOSIVE ACTIVITY}

Veniaminof Volcano is remote and at times not easily accessible or visible as it is commonly obscured by clouds and fog. Seismic monitoring of the volcano by the Alaska Volcano Observatory (AVO) commenced in 2002 [Dixon et al. 2019]; thus, records of eruptive activity prior to this time are limited to opportunistic aerial photographs and occasional observations. Regardless, observations made during eruptions in 1944, 1983-1984, 1992-1993, 2013, 2018 and 2021 all exhibited Strombolian explosive activity from vents in the summit crater of cone $\mathrm{A}$, and effusive lava flows emanating from flank vents on cone A occurring at the same time (Figure 2 and Figure 3).

The 1944 eruption was not well documented and little information is available to assess the duration and characteristics of this event. Archival photographs taken from a passing airplane clearly show cone A in active eruption (Figure 2A). This photograph shows what is likely a circular depression or melt pit in the ice surface and an associated steam plume on the lower flank of cone A. The depression was likely caused by subglacial melting and is plausible evidence for effusive subglacial eruption of lava from a flank vent. Explosive activity at the summit of cone A also is visible in the photograph.

The 1983-1984 eruption was first noticed by residents of Perryville, Alaska (Figure 1) who observed intermittent bursts of dark ash above cone A on June 2, 1983. Information about this eruption came from ob- servations made during aerial overflights of the volcano in June, July, and October, 1983, and January, 1984. Aerial observations made on June 6, 1983 indicated that an approximately $90-\mathrm{m}$-wide, $300-\mathrm{m}$-long graben, and a 400-m-diameter, 20-30 m deep, circular, ice cauldron in the caldera icefield immediately south of the cone A had formed (Figure 2B). These features record effusion of a subglacial lava flow from a subglacial vent on the southwest flank of cone A. At the same time, explosive ash emissions were occurring from vents in the summit crater of cone A (Figure 2B). An oblique aerial photograph taken on October 6, 1983 shows a subaerial vent effusing lava and explosive activity occurring at the summit crater of cone A (Figure 2C). By 1984, lava effusion from a flank vent had largely ceased, and about $0.3 \mathrm{~km}^{2}$ of lava erupted (Figure 3A) [Yount et al. 1985].

Eruptive activity at Veniaminof Volcano in 1993 was first observed by passing pilots who reported steam plumes rising from cone A in February 1993 [Neal et al. 1995]. Ash emissions were observed on July 30, 1993 and thereafter intermittently through August 12, 1993 when viewing conditions were good [Neal et al. 1996]. Low-level Strombolian ash emission from the summit crater of cone A was observed on August 3, 1993 (Figure 2A). Throughout the evening of October 7, residents of Perryville observed bursts of incandescent material rising approximately $300 \mathrm{~m}$ above the summit [Neal et al. 1996]. A U.S. Coast Guard overflight on November 6, 1993 confirmed the presence of a lava flow on the lower east flank of cone A. Low-level eruptive activity continued intermittently through the winter of 1993-1994 and occasional minor ash and steam emissions were observed by local residents [Neal et al. 1995; 1996]. Lava effusion on the flank of cone A and minor summit emissions were observed on during an AVO overflight of the volcano on May 9, 1994 (Figure 2E). Lava flows covering about $0.4 \mathrm{~km}^{2}$ were emplaced from a vent on the lower south flank of cone A (Figure 2E, Figure 3B), but no lava flows were erupted from the summit vent.

The 2013 eruption began on about June 13 after a seven-day period of gradually increasing levels of seismic tremor and ended by about October 17 [Dixon et al. 2015]. The initial pulse of eruptive activity consisted primarily of minor ash emissions on June 13. Elevated surface temperatures were observed at cone A in Advanced Very High Resolution Radiometer (AVHRR) satellite data on June 13 indicating the initial effusion of lava. From June 13-July 19, at least three lava flows were erupted on the southwest flank of cone A (Figure 3C). These flows extended a short distance beyond the base of the cone and began to slowly melt into the underlying snow and ice. After July 19, the source vent for the lava flows shifted to the northeast, and lava flows developed on the east-northeast flank of cone A (Figure 3C). These flows also extended a short distance beyond the base of the cone and began slowly melting into the underlying snow and ice. Numerous, low- 

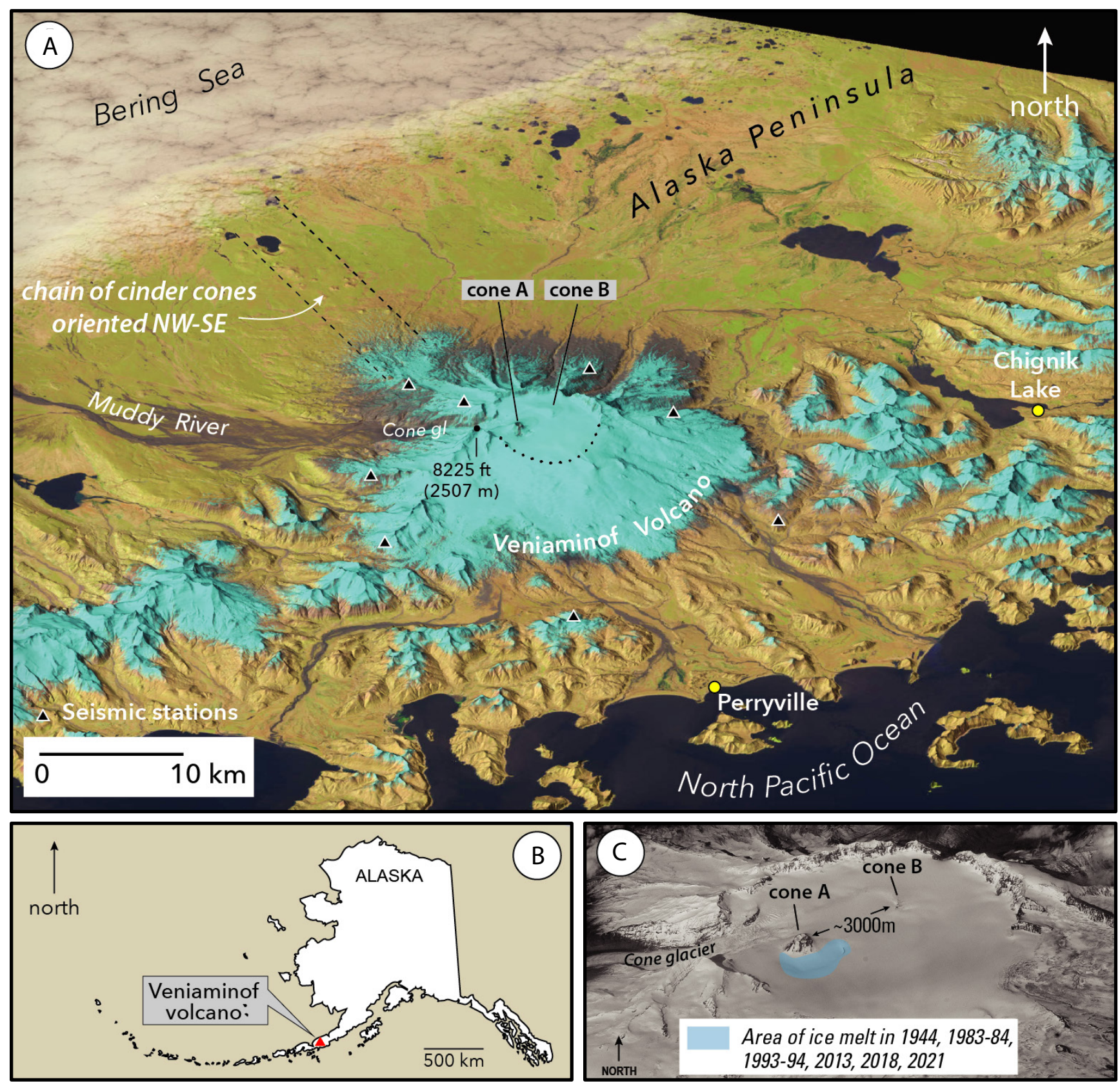

Figure 1: Location and setting of Veniaminof Volcano on the Alaska Peninsula. [A] Shaded relief image of Veniaminof Volcano and vicinity showing location of intracaldera cones $A$ and $B$. Cone $A$ has been the site of all known historical eruptive activity. Cone $B$ is an older intracaldera cone that is mostly covered by ice and snow and has had no known historical eruptions. Black triangles indicate seismic stations on the volcano; the seismic network has been operated by AVO since 2002. Dotted line shows approximate location of ice-covered caldera rim. [B] Location of Veniaminof Volcano on the Alaska Peninsula of southwest Alaska. [C] Oblique aerial photograph of the $8 \times 10 \mathrm{~km}$ diameter ice-filled caldera and areas inundated by lava flows in 1983-1984, 1993-1994, 2013, and 2018.

level ash plumes were generated between July 19 and early September, and ash fallout was generally limited to within the caldera, although trace ash fall was reported in Perryville on August 30. Photographs taken from locations inside the caldera on August 18, 2013 show simultaneous Strombolian explosive activity occurring at the summit crater vent and lava flow effusion from at least two vents on the lower northeast flank of cone A (Figure 2F, G).

On September 3, 2018 an increase in seismic tremor was detected at Veniaminof Volcano, heralding the onset of another period of unrest. Low-level ash emissions were observed on September 4, and by September 7, lava fountaining at cone A and small lava flows on the south flank of the cone were observed in both web camera and satellite images. Lava flows erupting 


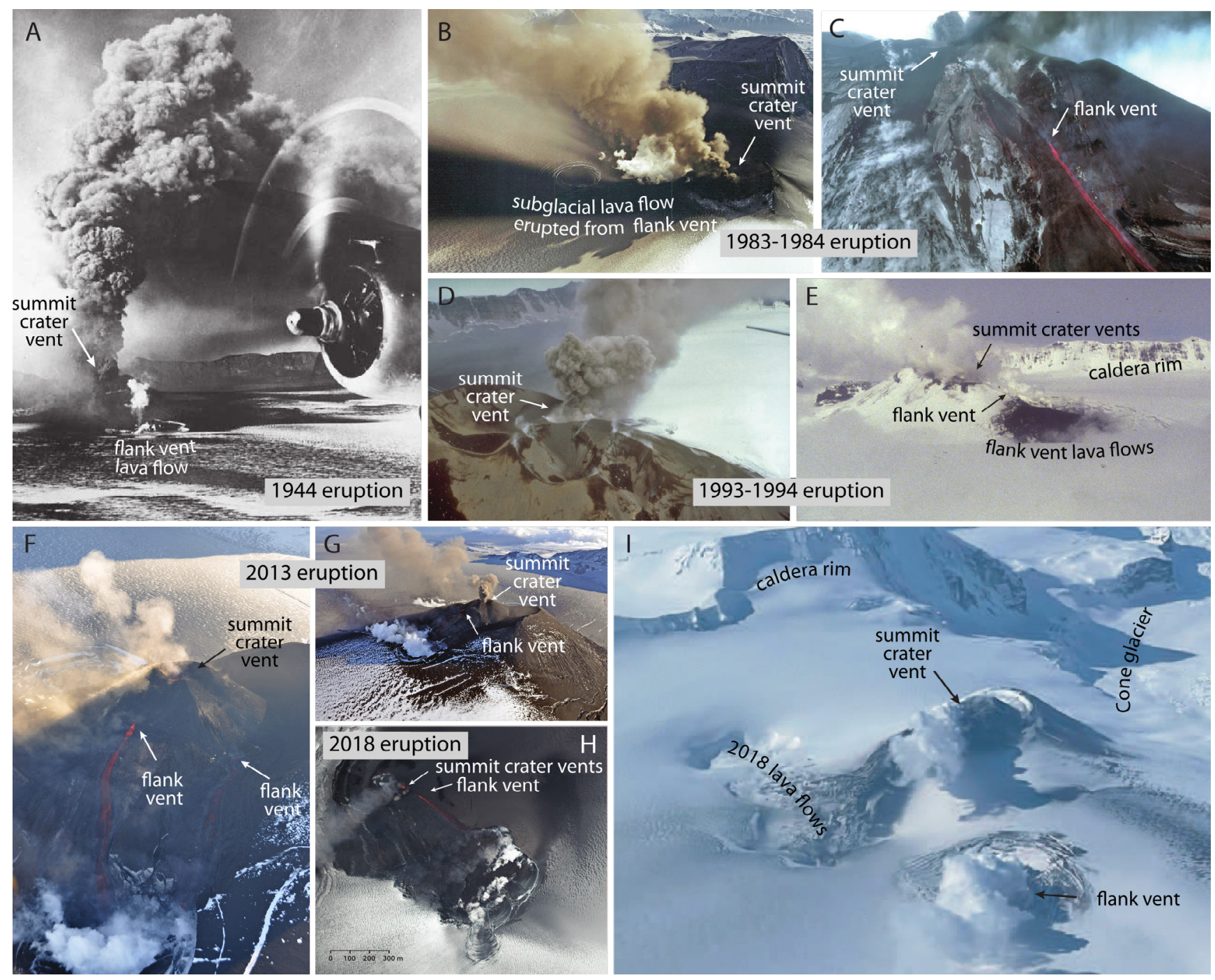

Figure 2: Representative photographs of the historically active intracaldera cone within the ice-filled caldera of Veniaminof Volcano showing simultaneous emission of ash and lava. [A] Ash emissions from summit vent and lava flow and melt depression at base of cone A, 1944. Photographer unknown. View is toward the north. [B] Ash emissions from summit vent and subglacial extrusion of lava from flank vent. June 6, 1983. Photo courtesy of Quantum Spatial. View is toward the west. [C] Simultaneous lava effusion and ash emission at cone A, October 7, 1983. Photo by E. Yount, USGS. View is toward the northeast. [D] Low-level Strombolian ash emission from the summit crater of cone A, August 3, 1993. Photo by D. Sellers, Alaska Department of Fish and Game. View is toward the southeast. [E] Oblique aerial photograph of cone A taken on fixed-wing aerial overflight, May 9, 1994 showing minor emissions at summit and flank vent lava flows. Photo by C. Nye, AVO. View is toward the north. [F], [G] August 18, 2013. Photos by R. McGimsey, USGS-AVO. Both views are toward the southwest. [H] September 26, 2018. Photo by M. Laker, US Fish and Wildlife Service. View is approximately vertical. [1] March 11, 2021. Although ash emission is obscured by vapor in this photograph, the summit vent was the only source of ash emission during the 2021 eruption. No other close-in photographs of the eruption are available. Photo by B.D. Jacob. View is toward the west.

from as many as four small vents on the south flank of cone A, were observed in satellite images acquired on September 11 and were photographed during an aerial overflight on September 26 (Figure $2 \mathrm{H}$ ). These images also showed simultaneous lava effusion from flank vents and explosive activity at the summit crater of cone A that continued throughout the duration of the 2018 eruption which ended by about December 27 .
During the 2018 eruption, at least two vents in the summit crater of the cone A were the origin of moderately explosive ash and steam emissions and minor lava fountaining (Figure $2 \mathrm{H}$ ). A second set of vents was located on the upper south flank of the cone A about $145 \mathrm{~m}$ southeast of the of the summit crater (Figure $2 \mathrm{H}$ ). Lava erupted from flank vents covered an area of about $0.6 \mathrm{~km}^{2}$ (Figure 3D); no lava flows developed 

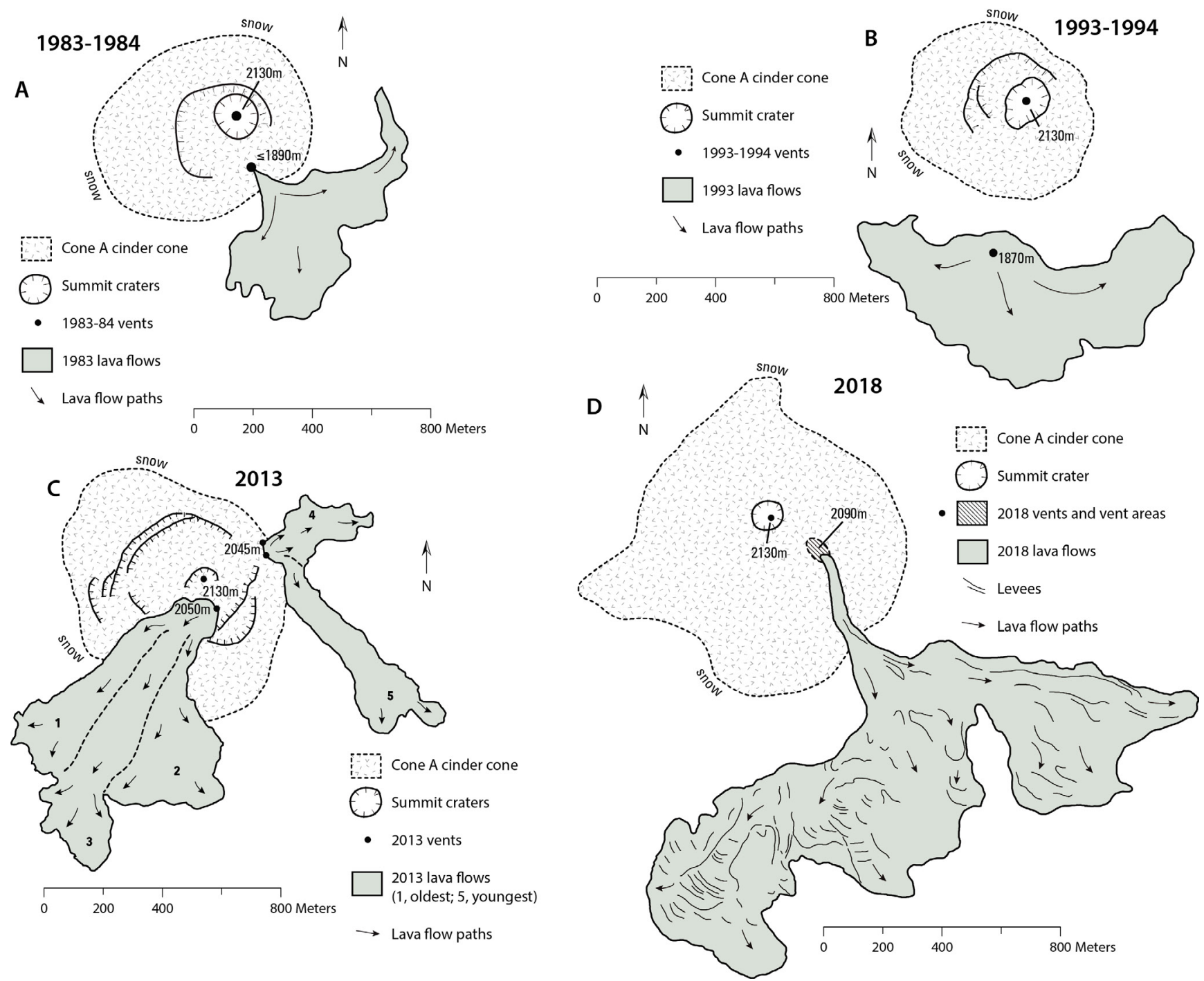

Figure 3: Geologic sketch maps of cone A at Veniaminof Volcano showing extent of lava flows and eruptive vents. The locations and altitudes of vents indicated on each map are approximate. Elevation data obtained from 2019 Alaska IfSAR data (https://elevation.alaska.gov). The dashed line outlining cone $A$ on each map is the contact with the surrounding snow and glacier ice. [A] Map of cone A showing lava flows and vents associated , with the 1983-1984 eruption. Base is vertical aerial photograph acquired in August 1983. [B] Map of cone A showing lava flows and vents associated with the 1993-1994 eruption. Base is vertical aerial photograph acquired in August 1993. [C] Map of cone A showing lava flows and vents associated with the 2013 eruption. Base is WorldView-1 satellite image. [D] Map of cone A showing lava flows and vents associated with the 2018 eruption. Base is WorldView-2 satellite image. [E] Map of cone A showing lava flows and approximate vent locations associated with the 2021 eruption. Base is WorldView-3 satellite image. 
at the summit vent. The dimensions of individual summit and flank vents were measured on high-resolution satellite images of cone A ( $<50 \mathrm{~cm}$ pixel resolution). These measurements indicate that the summit vents are on the order of 5-10 $\mathrm{m}$ in diameter and have areas of 25-100 $\mathrm{m}^{2}$. The flank vents are smaller, $1-2 \mathrm{~m}$ in diameter and $1-4 \mathrm{~m}^{2}$ in area.

On March 4, 2021, the combination of elevated surface temperatures at cone $\mathrm{A}$, detection of small, discrete explosions by infrasound sensors, and observations of ash emission in satellite and web camera images confirmed that a low-level eruption was underway. A high-resolution satellite image obtained on March 7 indicated that a subglacial vent about $1100 \mathrm{~m}$ east of cone A was erupting lava that resulted in the formation of a small ice cauldron. By March 7 the ice cauldron was about $600 \mathrm{~m}$ long, $550 \mathrm{~m}$ wide, and had an area of $2.5 \times 10^{5} \mathrm{~m}^{2}$. The March 7 satellite image also confirmed that minor explosive activity and ash emissions were occurring from the summit crater of Cone A, whereas the subglacial lava effusion was occurring from a separate vent on the flank of the cone (Figure 2I). Intermittent ash emission from the summit vent of cone $\mathrm{A}$, explosions, and lava effusion at a cluster of three vents within the ice cauldron continued into late March when the eruption gradually ended. By early April 2021, three separate lava flows with a combined area of about $2.7 \times 10^{4} \mathrm{~m}^{2}$ were visible on the floor of the ice cauldron (Figure $3 \mathrm{E}$ ).

The six examples portrayed in Figure 2 show that simultaneous lava effusion from flank vents and explosive ash emission from cone A summit vents is a characteristic feature of historical eruptive activity. Possible explanations for this eruptive style are discussed below.

\section{Simultaneous ERUPtive ACtivity AT Cin- DER CONES}

\subsection{Observations and examples}

Historical observations of cone A at Veniaminof Volcano indicate the transient development of effusive vents on the flanks of the cone at altitudes lower than the vents within the summit crater (Figure 2 and Figure 3). The location of these vents at altitudes of more than $50 \mathrm{~m}$ below the floor of the summit crater lends support to the inference that a branching conduit system is a feature of the shallow magmatic system at cone A. These observations also are supported by various field studies of small-volume basaltic cinder cones and volcanoes that have documented the existence of feeder dikes with branching, T shapes at depths of 100-250 m below the surface that have widths on the order of 4$12 \mathrm{~m}$ [Keating et al. 2008] similar to what is inferred for cone A.

Most cinder cones are the products of Strombolian explosions where lapilli and bombs accumulate on the cone flanks at the angle of repose for this material [3033 : Vespermann and Schmincke 2000; Valentine et al. 2005]. Many cinder cones have associated lava flows [Vespermann and Schmincke 2000] and in some cases lava effusion and explosive activity have occurred simultaneously from different vents, for example during the 1943-1952 eruption of Parícutin Volcano, Mexico [White 1944; Krauskopf 1948], the 2001 eruption of Mt. Etna, Italy [Behncke and Neri 2003] and at Irao volcano, Japan [Kiyosugi et al. 2013]. This type of behavior implies partitioning of the magmatic plumbing system such that lateral and vertical branches of the conduit network each have unique roles and functions.

Dual vents and simultaneous effusive and explosive activity at Parícutin were examined by Pioli et al. [2009]. This analysis showed (1) that branching of the conduit system into vertical and lateral components was a shallow feature ( $<1 \mathrm{~km}$ depth); (2) that magmatic volatiles became preferentially segregated into the vertical part of the conduit; and (3) the partitioning of magma into the vertical and lateral branches was a function of the mass eruption rate. Pioli et al. [2009] further suggested that the formation of lateral vents can increase the degree of explosivity at summit vents fed by the vertical branch of the conduit network such that violent Strombolian activity [Macdonald 1972] is favored by this configuration.

\subsection{Why do magma filled volcanic conduits bifurcate?}

Branching conduits have been described in field studies of small-volume volcanoes and cinder cones where the volcanic plumbing system has been exposed by erosion [Valentine and Krogh 2006; Valentine and Keating 2007; Keating et al. 2008; Hintz and Valentine 2012]. At East Basalt Ridge and Paiute Ridge in southwest Nevada, feeder dikes extend vertically from depth and then exhibit lateral branching within 50-90 of the surface [Keating et al. 2008]. In these examples, various heterogeneities in the upper edifice, such as bedding, discontinuities, lithologic contacts, and unconformities are inferred to promote the development of shallow $(<100 \mathrm{~m})$ conduit branches.

The orientation of dikes is related to the local stress field [Nakamura et al. 1977; Rubin and Pollard 1988]. In general, major dikes are oriented roughly parallel to the maximum compressive stress and in Aleutian arc this is approximately normal to the Aleutian trench [Tibaldi and Bonali 2017]. Models of dike propagation in volcanic edifices where branching or dike segmentation occurs have been related to local variations in the stress field associated with a shallow magma reservoir or mode of host rock fracture that influences the motion of the dike tip resulting in bifurcation [Pollard et al. 1982; Acocella and Neri 2009; Rivalta et al. 2015]. Branching and splaying in buoyantly rising dikes also can be related to the fluid-mechanical behavior of the 


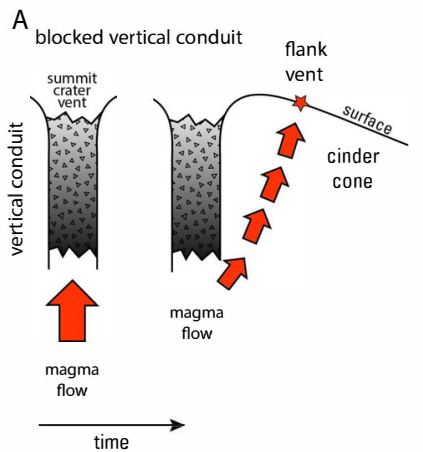

B open vertical conduit

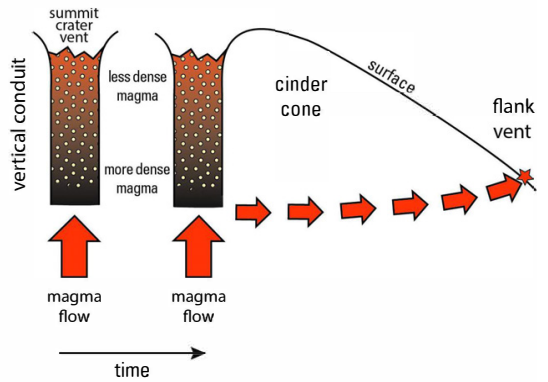

Figure 4: Conceptual models of shallow magma flow at Veniaminof Volcano. [A] Upward flow of magma encounters plugged, lava-filled conduit. Flow is diverted because of structurally weak conduit walls. [B] Magma within the conduit degasses and becomes density stratified. The denser, more degassed magma propagates laterally, reaches the cone flank and erupts as effusive lava. [C] Magma moving toward the surface encounters the T-junction and the flow becomes partitioned. The more gasrich part of the flow segregates into the vertical part of the conduit and is responsible for explosive Strombolian activity from the summit vent. The gas-poor part of the flow exits via the lateral branch and erupts as effusive lava on the flanks. Because of this configuration, recirculation eddies develop downstream of the T-junction and this behavior may contribute to the steady non-harmonic tremor that characterizes cone A eruptions. Modified from Alp [2009].

dike tip and to natural heterogeneities of the host material [Roper and Lister 2007; Touvet et al. 2011]. Lateral dikes also can develop if rising magma in the central conduit becomes blocked or impeded (Figure 4A) and imparts localized and possibly temporary loading on the conduit such that the magma pressure in the conduit exceeds the strength of conduit walls [Acocella et al. 2006; Kervyn et al. 2009]. This latter mechanism is relevant to cone A at Veniaminof Volcano because of the shallow branching behavior observed and because tectonic controls and lithostatic pressure effects on dike propagation in this setting (small, shallow cone A edifice) are likely less important. Studies of shallow dike emplacement at Mount Vesuvius indicate that vertical propagation of dikes is associated with a closed or solidified central conduit (Figure 4A), whereas lateral dike emplacement is commonly associated with an open central conduit [Figure 4B; Acocella et al. 2006]. If magma in the upper part of an open conduit degasses and becomes denser, it is more likely to propagate laterally [Acocella et al. 2006]. In either case, the branching conduit takes on a roughly $\mathrm{T}$-shaped configuration shown in a generalized representation in Figure $4 \mathrm{C}$.

\subsection{T-junction volcanic conduits}

Multiphase flow through branching networks and Tjunctions has been studied extensively because of its importance in the petrochemical and nuclear power industries [Azzopardi 1993; Das et al. 2005]. Var- ious types of flows, including bubbly, annular, and slug flows have been analyzed computationally and such results have applicability to understanding flow of magma in branching volcanic conduits. For a simple T-junction conduit configuration that conveys a twophase flow, the T-junction acts as a flow diverter and as a flow separator (Figure $4 \mathrm{C}$ ). In the flow separation case, all or part of one phase may be removed by the T-junction [Azzopardi et al. 2002].

In rising magmas, flow separation caused by conduit T-junctions can affect the distribution of liquid and gas phases such that exsolved gas stays within the vertically oriented and typically larger conduit and this can drive explosive activity at summit vents above [Pioli et al. 2009]. Smaller diameter lateral dikes feeding flank vents in this scenario would be gas-poor by comparison and erupt primarily effusive lavas. This is observed at cone A on Veniaminof Volcano where the active vents are smaller on the cone flanks than at the cone summit (Figure 2).

Numerical simulation of air-water mixtures flowing across a T-junction using finite-volume techniques shows that more flow into the lateral branch occurs as the pressure $(p)$ difference increases where $p_{\text {vertical }}>$ $p_{\text {branch. }}$ A pressure increase in the vertical conduit is in part a result of the relationship between flow speed and pressure such that a decline in fluid speed in the vertical conduit caused by lateral flow in a T-junction results in an increase in $p_{\text {vertical }}$ according to the Bernoulli principle. As the flow rate (or mass eruption rate) increases however, less of the flow is diverted into the 
lateral branch as a result of greater flow inertia and a lower degree of gas segregation [Alp 2009; Pioli et al. 2009]. The finite-volume modeling studies of Alp also showed that two-phase flows form recirculation eddies downstream of T-junctions (Figure 3). It is possible that these features develop during cone A eruptions at Veniaminof Volcano and could contribute to the steady non-harmonic tremor that characterizes all of the seismically monitored historical eruptions.

\section{Discussion}

The observations of simultaneous effusive and explosive activity at Veniaminof Volcano suggests that flow separation within the shallow conduit network is likely occurring and this could be a consequence of a $\mathrm{T}$ junction like configuration of the conduit in the upper part of cone A. Application of the results of the modeling studies described above to observations of cinder cone eruptions at Veniaminof Volcano (Table 1) also are consistent with the inference of a T-junction type shallow conduit system at cone A. Simultaneous effusive and explosive eruptive activity generally occurs at cinder cones when mass eruption rates are about $10^{3}-10^{5} \mathrm{~kg} \mathrm{~s}^{-1}$ [Pioli et al. 2009]; the maximum ash cloud heights $(H)$ associated with simultaneous activity at cone $\mathrm{A}$ when converted to mass eruption rate (MER) using the empirical formula MER $=140\left(H^{4.14}\right)$ [Mastin et al. 2009; Mastin 2014] are within this range (Figure 5). The historical eruptions that had the highest ash clouds (and likely the highest mass eruption rates) are also the eruptions where simultaneous summit and flank activity was observed (Figure 5). The average ash cloud height during eruptions with simultaneous summit and flank activity was roughly $1600 \mathrm{~m}$ higher than during eruptions with summit activity only. This suggests that at times during the eruptions in 1983-1984, 1993-1994, 2013, 2018, 2021, and possibly in 1944, flow partitioning of shallow magma occurred and preferential volatile segregation into the vertical part of the T-junction conduit system likely took place. During future cone A eruptions, the development of simultaneously erupting summit and flank vents suggests that ash clouds could extend higher than they do when only summit activity occurs. Higher rising ash clouds would be more hazardous to aircraft and could produce ash fallout beyond the Veniaminof caldera.

The location of vents at cone A has varied over the recent period of historical observations beginning in 1944. However, it is not entirely clear what controls the vent locations within Veniaminof caldera. The historically active vents at cone $A$ and the location of the other intracaldera cone (cone $\mathrm{B}$ ) have a general northeastsouthwest orientation (Figure 6). This contrasts with the northwest-southeast orientation of flank vents and cinder cones north of Veniaminof Volcano [Figure 6: Nakamura et al. 1977; Tibaldi and Bonali 2017]. These

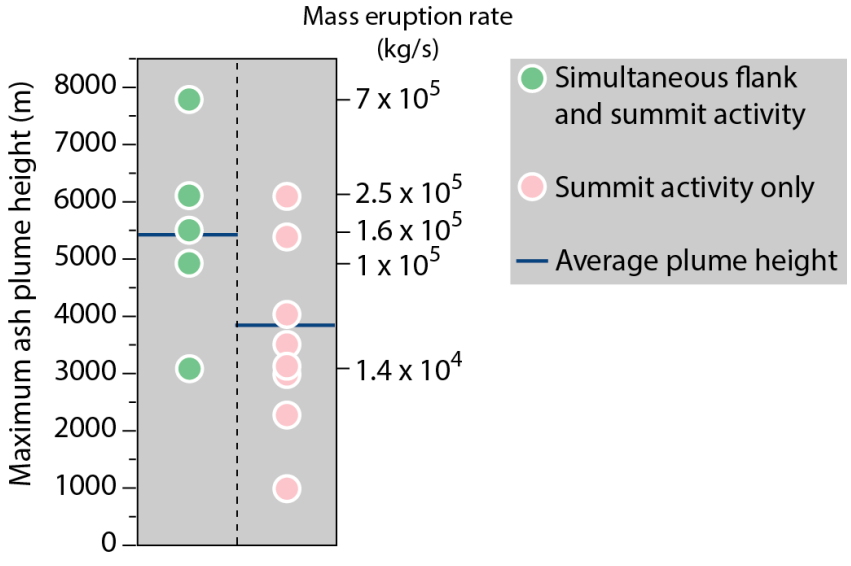

Figure 5: Maximum ash-cloud height (above sea level), mass eruption rate and location of historical eruptive activity at cone A of Veniaminof Volcano. Historical eruptions with simultaneous summit and flank activity produced slightly higher rising ash clouds that could have been a consequence of the partitioning of more gascharged magma into the vertical conduit of a T-junction type conduit system. Mass eruption rates estimated using method described in Mastin [2014].

studies have shown that the greatest principal horizontal stress in the Aleutian arc is oriented northwestsoutheast and that the preferred magma pathways coincide with the regional stress field such that dikes are emplaced roughly normal to the orientation of the arc [Nakamura et al. 1977; Tibaldi and Bonali 2017]. The orientation of the vents associated with intracaldera eruptive activity and simultaneous explosive and effusive activity at cone A suggest magma pathways that are oriented parallel with the minimum principal horizontal stress in this part of the Aleutian arc. If the postcaldera development of cinder cones and flank vents at Veniaminof reflects sustained dike intrusion parallel to the greatest principal horizontal stress (northwestsoutheast), it may be that associated inflation within the caldera has increased the stress normal to the dike orientation such that a new, but local, greatest principal horizontal stress field has developed [Tibaldi and Bonali 2017] and is oriented northeast-southwest. Minor amounts of inflation have been detected at Veniaminof Volcano [Fournier and Freymueller 2008] so it is plausible that the youngest vents and their associated feeder dikes are forming in response to this local change in stress regime. At shallow levels within cone A, the location of individual vents could have more to do with local irregularities such as weak versus strong conduit boundaries and the type of stratification within the cone as discussed previously. It is worth noting that all vents documented on cone A since 1944 have developed on the southern hemisphere of the cone south of a northeast-southwest trending line that bisects cone A. 


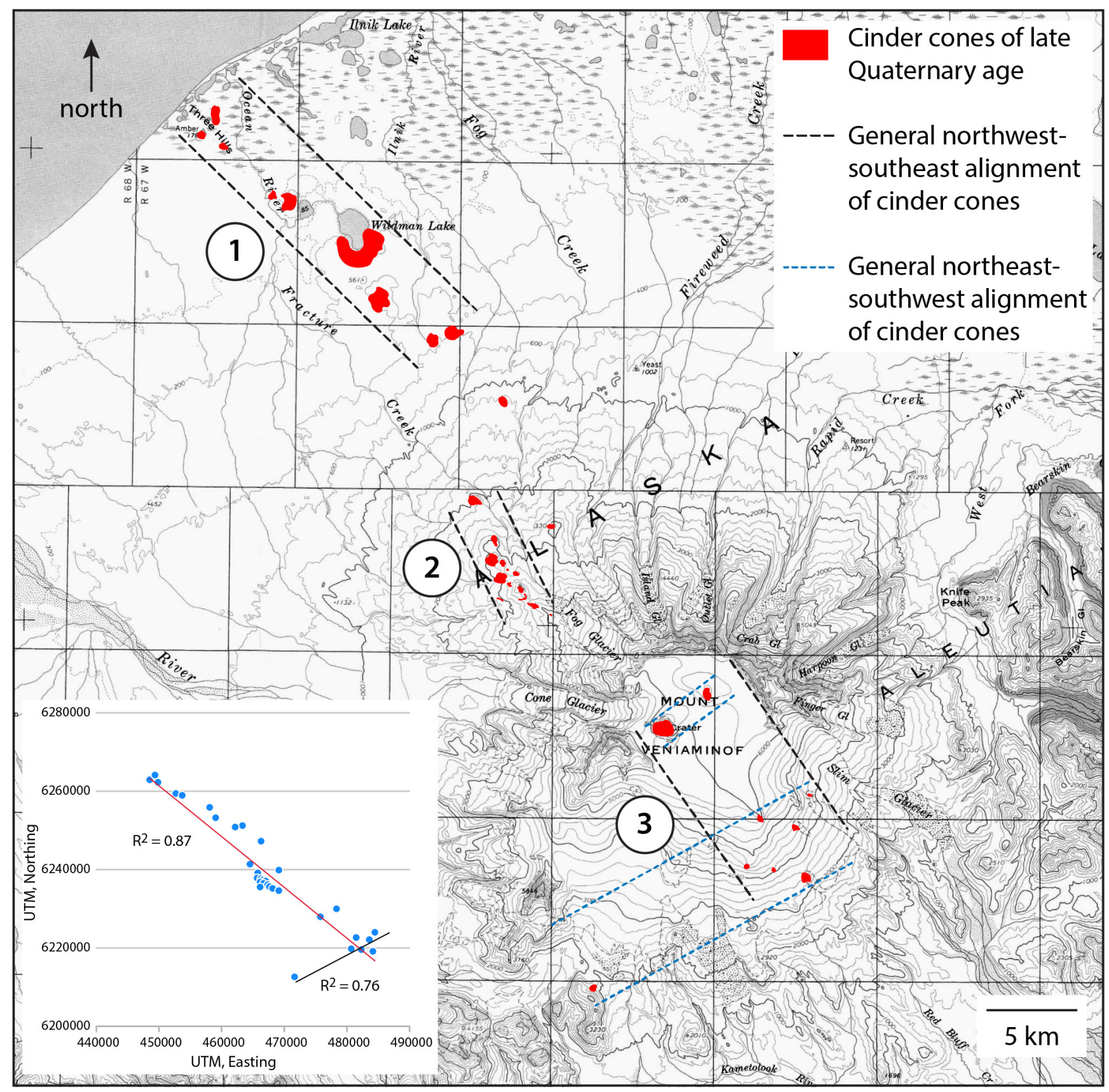

Figure 6: Cinder cones at Veniaminof Volcano. Three clusters of cinder cones are apparent. Cluster 1 is the oldest and these cones are partly to entirely vegetated and are mantled with pyroclastic deposits associated with a mid-late Holocene caldera-forming eruption of Veniaminof. Cluster 2 is intermediate in age and these cones are sparsely vegetated and lack a pyroclastic cover, indicating that they are younger than the last calderaforming eruption. Cluster 3 includes the historically active cone inside the caldera (cone A), cone B, and several fresh unvegetated, unglaciated cones on the south flank of the edifice. The dashed lines indicate the general spatial alignment of the cone clusters. Note that it is unclear if the cones of group 3 have a northwest-southeast orientation or a northeast-southwest orientation. Plot in lower left gives the location of the cinder cones in UTM coordinates and shows a strong linear alignment $\left(R^{2}=0.87\right)$. A plausible northeast-southwest orientation of the group-3 cinder cones is indicated by the black line $\left(R^{2}=0.76\right)$. 


\section{SUMMARY AND CONCLUSIONS}

Simultaneous effusive and explosive eruptive activity introduces a number of heuristic concerns regarding branching volcanic conduits and their role in influencing eruptive style. At Veniaminof Volcano, simultaneous explosive and effusive activity has occurred during at least six of nineteen documented historical eruptions from an intracaldera cinder cone. The simultaneous activity is likely the result of a T-junction like conduit network within the upper $500-1000 \mathrm{~m}$ of the cone. Gas-magma segregation resulting from a T-junction structure could have led to slightly more powerful gas-driven ash bursts as there is a plausible correlation of these events with simultaneous lava effusion. Cone A at Veniaminof Volcano is one of the more frequently active eruptive centers in the Aleutian arc and is likely to have additional eruptions over the next several decades. That individual eruptive episodes can manifest themselves in such disparate ways also has important implications for volcano monitoring and the design of appropriate geophysical networks capable of detecting multiple versus single vent eruptions. Thus, during future eruptions, close-in (as opposed to regional) dense station geophysical monitoring and observations within 1-2 km of cone A employing threecomponent seismic instruments, infrasound, continuous gas emission, time-lapse cameras, and geodetic measurements would be helpful in detecting subtle changes in vent location and eruptive behavior and for testing the interpretations presented here.

\section{Acknowledgements}

The author wishes to thank J. Power, L. Mastin, and the two anonymous journal reviewers for their constructive reviews and comments which helped clarify some of the ideas presented.

\section{Data aVailability}

The datasets generated during and/or analyzed during the current study are available from the corresponding author on reasonable request.

\section{COPYRIGHT NOTICE}

(C) The Author(s) 2021. This article is distributed under the terms of the Creative Commons Attribution 4.0 International License, which permits unrestricted use, distribution, and reproduction in any medium, provided you give appropriate credit to the original author(s) and the source, provide a link to the Creative Commons license, and indicate if changes were made.

\section{REFERENCES}

Acocella, V. and M. Neri (2009). "Dike propagation in volcanic edifices: Overview and possible developments". Tectonophysics 471 (1-2), pp. 67-77. DoI: 10 . 1016/j. tecto.2008.10.002.

Acocella, V., M. Neri, and P. Scarlato (2006). "Understanding shallow magma emplacement at volcanoes: Orthogonal feeder dikes during the 2002-2003 Stromboli (Italy) eruption". Geophysical Research Letters 33 (17). DoI: 10.1029/2006glo26862.

Alp, D. (2009). "Numerical Modeling of Natural Gas Two-Phase Flow Split at Branching T-Junctions with Closed-Loop Network Applications". PhD thesis. Pennsylvania State University.

Azzopardi, B. J. (1993). "T junctions as phase separators for gas liquid flows: possibilities and problems". Chemical Engineering Research and Design 71 (3), pp. 273-281.

Azzopardi, B. J., D. A. Colman, and D. Nicholson (2002). "Plant Application of a T-Junction as a Partial Phase Separator". Chemical Engineering Research and Design 80 (1), pp. 87-96. Dor: 10.1205/ 026387602753393394.

Bacon, C. R., T. W. Sisson, and F. K. Mazdab (2007). "Young cumulate complex beneath Veniaminof caldera, Aleutian arc, dated by zircon in erupted plutonic blocks". Geology 35 (6), pp. 491494. Dor: $10.1130 / g 23446 a .1$.

Behncke, B. and M. Neri (2003). "The July-August 2001 eruption of Mt. Etna (Sicily)". Bulletin of Volcanology 65 (7), pp. 461-476. DOI: 10.1007/s00445-003-02741.

Calvert, A. T., C. R. Bacon, and T. W. Sisson (2005). "Argon Geochronology of Lavas at Mt. Veniaminof Volcano Dates Pleistocene Climatic Events on the Alaska Peninsula". AGU Fall Meeting Abstracts. Vol. 2005, pp. V13D-0573.

Cassidy, M., M. Manga, K. Cashman, and O. Bachmann (2018). "Controls on explosive-effusive volcanic eruption styles". Nature Communications 9 (1). DOI: $10.1038 / \mathrm{s} 41467-018-05293-3$.

Das, G., P. K. Das, and B. J. Azzopardi (2005). "The split of stratified gas-liquid flow at a small diameter Tjunction". International Journal of Multiphase Flow 31 (4), pp. 514-528. Dor: 10.1016/j . i jmultiphaseflow. 2005.01.009.

Detterman, R. L., T. P. Miller, M. E. Yount, and F. H. Wilson (1981). Quaternary geologic map of the Chignik and Sutwik Island quadrangles, Alaska. Tech. rep. DoI: 10.3133/i1292. [Map I 1292].

Dixon, J. P., C. Cameron, R. G. McGimsey, C. A. Neal, and C. Waythomas (2015). 2013 volcanic activity in Alaska: summary of events and response of the Alaska Volcano Observatory. DoI: 10.3133/sir20155110. [Scientific Investigations Report 2015-5110].

Dixon, J. P., S. D. Stihler, M. M. Haney, J. J. Lyons, D. M. Ketner, K. M. Mulliken, T. Parker, and J. A. 
Power (2019). Catalog of earthquake parameters and description of seismograph and infrasound stations at Alaskan volcanoes-January 1, 2013, through December 31, 2017. DoI: 10.3133/ds1115. [Data Series 1115].

Fournier, T. and J. Freymueller (2008). "Inflation detected at Mount Veniaminof, Alaska, with campaign GPS". Geophysical Research Letters 35 (20). DoI: 10 . 1029/2008gl035503.

Hintz, A. R. and G. A. Valentine (2012). "Complex plumbing of monogenetic scoria cones: New insights from the Lunar Crater Volcanic Field (Nevada, USA)". Journal of Volcanology and Geothermal Research 239-240, pp. 19-32. DoI: $10.1016 / \mathrm{j}$. jvolgeores . 2012.06 .008$.

Jordan, S. C., J.-L. Le Pennec, L. Gurioli, O. Roche, and P. Boivin (2016). "Highly explosive eruption of the monogenetic 8.6 ka BP La Vache et Lassolas scoria cone complex (Chaine des Puys, France)". Journal of Volcanology and Geothermal Research 313, pp. 15-28. DoI: 10.1016/j . jvolgeores. 2015.12.006.

Keating, G. N., G. A. Valentine, D. J. Krier, and F. V. Perry (2008). "Shallow plumbing systems for smallvolume basaltic volcanoes". Bulletin of Volcanology 70 (5), pp. 563-582. DoI: 10.1007/s00445-007-0154-1.

Kervyn, M., G. G. J. Ernst, B. van Wyk de Vries, L. Mathieu, and P. Jacobs (2009). "Volcano load control on dyke propagation and vent distribution: Insights from analogue modeling". Journal of Geophysical Research 114 (B3). DoI: 10.1029/2008jb005653.

Kiyosugi, K., Y. Horikawa, T. Nagao, T. Itaya, C. B. Connor, and K. Tanaka (2013). "Scoria cone formation through a violent Strombolian eruption: Irao Volcano, SW Japan". Bulletin of Volcanology 76 (1). Dor: 10.1007/s00445-013-0781-7.

Krauskopf, K. B. (1948). "Mechanism of eruption at Parícutin volcano, Mexico". Geological Society of America Bulletin 59 (8), p. 711. DoI: 10.1130/00167606 (1948) 59[711:moeapv]2.0.co; 2 .

Loewen, M. W., H. R. Dietterich, N. Graham, and P. Izbekov (2021). "Evolution in eruptive style of the 2018 eruption of Veniaminof volcano, Alaska, reflected in groundmass textures and remote sensing". Bulletin of Volcanology 83 (11). DOI: 10.1007/s00445021-01489-6.

Luhr, J. F., T. Simkin, and M. Cuasay, eds. (1993). Parícutin: the volcano born in a Mexican cornfield. Phoenix, AZ: US Geoscience Press.

Macdonald, G. A. (1972). Volcanoes. Englewood Cliffs, New Jersey: Prentice-Hall Inc.

Mastin, L. G. (2014). "Testing the accuracy of a 1-D volcanic plume model in estimating mass eruption rate". Journal of Geothermal Research: Atmospheres 119 (5), pp. 2474-2495. Dor: 10.1002/2013jd020604.

Mastin, L. G., M. Guffanti, R. Servranckx, P. Webley, S. Barsotti, K. Dean, A. Durant, J. Ewert, A. Neri, W. Rose, and et al. (2009). "A multidisciplinary effort to assign realistic source parameters to models of volcanic ash-cloud transport and dispersion dur- ing eruptions". Journal of Volcanology and Geothermal Research 186 (1-2), pp. 10-21. DOI: 10.1016/j . jvolgeores.2009.01.008.

Miller, T. P., R. G. McGimsey, D. H. Richter, J. R. Riehle, C. Nye, M. Yount, and J. A. Dumoulin (1998). Catalog of the historically active volcanoes of Alaska. Dor: 10 . 3133/ofr98582. [Open-File Report 98-582].

Miller, T. P. and R. L. Smith (1987). "Late Quaternary caldera-forming eruptions in the eastern Aleutian arc, Alaska". Geology 15 (5), p. 434 . Dor: 10. 1130/0091-7613(1987) 15<434: lqceit>2 . 0.co; 2.

Miller, T. P., C. F. Waythomas, and J. E. Gardner (2002). "Possible Multiple Late Quaternary CalderaForming Eruptions at Mount Veniaminof Volcano, Alaska Peninsula". AGU Fall Meeting Abstracts. Vol. 2002, V11A-1376.

Nakamura, K., K. H. Jacob, and J. N. Davies (1977). "Volcanoes as possible indicators of tectonic stress orientation - Aleutians and Alaska". Pure and Applied Geophysics 115 (1-2), pp. 87-112. Dor: 10.1007/ bf01637099.

Neal, C. A., M. P. Doukas, and R. G. McGimsey (1995). 1994 Volcanic activity in Alaska: summary of events and response of the Alaska Volcano Observatory. DoI: 10. 3133/ofr95271. [Open-File Report 95-271].

Neal, C. A., R. G. McGimsey, and M. P. Doukas (1996). Volcanic activity in Alaska: summary of events and response of the Alaska Volcano Observatory 1993. DoI: 10.3133/ofr9624. [Open-File Report 96-24].

Pioli, L., B. J. Azzopardi, and K. V. Cashman (2009). "Controls on the explosivity of scoria cone eruptions: Magma segregation at conduit junctions". Journal of Volcanology and Geothermal Research 186 (3-4), pp. 407-415. DOr: 10.1016/j . jvolgeores . 2009 . 07. 014.

Pioli, L., E. Erlund, E. Johnson, K. Cashman, P. Wallace, M. Rosi, and H. D. Granados (2008). "Explosive dynamics of violent Strombolian eruptions: The eruption of Parícutin Volcano 1943-1952 (Mexico)". Earth and Planetary Science Letters 271 (1-4), pp. 359-368. DOI: $10.1016 / \mathrm{j}$. eps 1.2008 .04 .026$.

Pollard, D. D., P. Segall, and P. T. Delaney (1982). "Formation and interpretation of dilatant echelon cracks". 93 (12), p. 1291 . DoI: $10.1130 / 0016-$ 7606 (1982) 93<1291: faiode>2.0.co; 2 .

Rivalta, E., B. Taisne, A. Bunger, and R. F. Katz (2015). "A review of mechanical models of dike propagation: Schools of thought, results and future directions". Tectonophysics 638, pp. 1-42. Dor: 10.1016/j . tecto. 2014.10.003.

Roper, S. M. and J. R. Lister (2007). "Buoyancy-driven crack propagation: the limit of large fracture toughness". Journal of Fluid Mechanics 580, pp. 359-380. DoI: $10.1017 / \mathrm{s} 0022112007005472$.

Rubin, A. M. and D. D. Pollard (1988). "Dike-induced faulting in rift zones of Iceland and Afar". Geology 16 (5), p. 413. Dor: 10.1130/0091-7613(1988) $016<0413$ : difirz>2.3.co;2. 
Smith, I. E. M. and K. Németh (2017). "Source to surface model of monogenetic volcanism: a critical review". Geological Society, London, Special Publications 446 (1), pp. 1-28. Dor: 10.1144/sp446. 14.

Tibaldi, A. and F. L. Bonali (2017). "Intra-arc and backarc volcano-tectonics: Magma pathways at Holocene Alaska-Aleutian volcanoes". Earth-Science Reviews 167, pp. 1-26. Dor: $10.1016 /$ j . earscirev . 2017. 02.004.

Touvet, T., N. J. Balmforth, R. V. Craster, and B. R. Sutherland (2011). "Fingering instability in buoyancy-driven fluid-filled cracks". Journal of Fluid Mechanics 672, pp. 60-77. DoI: 10 . 1017 / s0022112010005860.

Valentine, G. A. and G. N. Keating (2007). "Eruptive styles and inferences about plumbing systems at Hidden Cone and Little Black Peak scoria cone volcanoes (Nevada, U.S.A.)" Bulletin of Volcanology 70 (1), pp. 105-113. Dor: 10.1007/s00445-007-0123-8.

Valentine, G. A., D. Krier, F. V. Perry, and G. Heiken (2005). "Scoria cone construction mechanisms, Lathrop Wells volcano, southern Nevada, USA". 33 (8), pp. 629-632. DoI: 10.1130/g21459ar. 1.

Valentine, G. A., D. J. Krier, F. V. Perry, and G. Heiken (2007). "Eruptive and geomorphic processes at the
Lathrop Wells scoria cone volcano". Journal of Volcanology and Geothermal Research 161 (1-2), pp. 5780. DoI: $10.1016 / \mathrm{j}$. jvolgeores.2006.11.003.

Valentine, G. A. and K. Krogh (2006). "Emplacement of shallow dikes and sills beneath a small basaltic volcanic center - The role of pre-existing structure (Paiute Ridge, southern Nevada, USA)”. 246 (3-4), pp. 217-230. Dor: 10.1016/j .epsl.2006.04.031.

Vespermann, D. and H.-U. Schmincke (2000). "Scoria cones and tuff rings". Encyclopedia of volcanoes. Ed. by H. Sigurdsson, B. F. Houghton, H. Rymer, J. Stix, and S. McNutt. Academic Press, pp. 683-694.

Waythomas, C. F., T. P. Miller, and K. Wallace (2015). "Surficial Geologic Map of Mount Veniaminof Volcano, Alaska". AGU Fall Meeting Abstracts. Vol. 2015, V33B-3091.

White, D. E. (1944). "Parıcutin's cyclic activity". 25 (4), p. 621. DoI: $10.1029 / \operatorname{tr} 025 i 004$ p00621.

Yount, M. E., T. P. Miller, R. P. Emanuel, and F. H. Wilson (1985). "Eruption in an ice-filled caldera, Mount Veniaminof, Alaska Peninsula”. The United States Geological Survey in Alaska: Accomplishments During 1983. Ed. by S. Bartsch-Winkler and K. M. Reed. Vol. 945. US Geological Survey, pp. 59-60. 